\title{
A responsabilidade do Poder Judiciário na proteção do meio ambiente cultural: o caso da Cervejaria Adriática
}

\section{The responsibility of the judiciary in the protection of cultural environment: Adriática Bewery case}

\author{
Giovanna Paola Primor Ribas* \\ Carlos Frederico Marés de Souza Filho*
}

\section{Resumo}

A demolição da Cervejaria Adriática, situada na cidade de Ponta Grossa, Paraná, foi objeto de ação civil pública proposta pelo Ministério Público, que visava o reconhecimento, pelo Estado, do valor histórico-cultural do bem em litígio. O pedido foi julgado improcedente em primeira e segunda instância, sob o fundamento de que o Poder Judiciário não seria ente legítimo, num Estado Social Democrático de Direito, para reconhecer um bem como cultural - atribuição cabível apenas ao Executivo. A presente pesquisa visou discutir a possibilidade de o Poder Judiciário, no Brasil atual, declarar um bem como patrimônio cultural, reavaliando a função do Judiciário frente às suas responsabilidades sociais. Ainda pretendeu-se verificar, no caso estudado, o comprometimento do Judiciário com os valores prescritos na Constituição, seja numa função política, seja como fiscal dos atos da Administração. Para tanto, utilizou-se a pesquisa bibliográfica e documental. Sob o prisma do

Doutoranda em Direito Econômico e Socioambiental pela Pontifícia Universidade Católica do Paraná. Mestre em Ciências Sociais Aplicadas pela Universidade Estadual de Ponta Grossa (UEPG), PR. Bacharel em Direito pela Universidade Estadual de Ponta Grossa (UEPG), PR. Professora em Direito Ambiental pela Faculdade Secal. Advogada. Presidente da Comissão de Meio Ambiente da OAB - Subseção de Ponta Grossa. Curitiba - PR - Brasil. Email: giovanna@ veros.adv.br

* Doutor em Direito pela Universidade Federal do Paraná. Mestre em Direito pela Universidade Federal do Paraná. Graduado em Direito pela Universidade Federal do Paraná. É procurador do Estado do Paraná desde 1981. Professor titular de Direito Agrário e Socioambiental no programa de mestrado e doutorado da Pontifícia Universidade Católica do Paraná. Membro do Conselho Diretor do Instituto Latinoamericano de Servicios Legales Alternativos-ILSA (Bogotá). Membro da Diretoria do Instituto Brasileiro de Advocacia Pública. Sócio fundador do Instituto SocioambientalISA. Procurador do Estado do Paraná. Curitiba - PR - Brasil. 
fenômeno do neoconstitucionalismo, as decisões judiciais foram confrontadas com a importância histórica do bem em questão e verificou-se uma flagrante incongruência entre o sistema jurídico constitucional e a atuação do Judiciário no estado do Paraná. Concluiu-se que o Poder Judiciário era legitimado para determinar o tombamento no caso estudado e que um bem cultural de extrema importância histórica para a sociedade de Ponta Grossa foi destruído com a anuência do Estado.

Palavras-chave: Patrimônio cultural. Proteção. Judiciário.

\section{Abstract}

The demolition of the Adriática Brewery, located in the city of Ponta Grossa, Paraná, was the object of public civil suit filed by prosecutors. This lawsuit sought recognition by the State of historical and cultural value of the good in dispute. The application was dismissed at first and second instance, on the grounds that the Judiciary would not be legitimate entity in a Legal Democratic Social State to recognize a cultural value of a good because this task allowed only to the Executive. This research aimed to discuss the possibility of the Judiciary, the Brazil Current, declaring a good as being cultural heritage, revealing the function of the Judiciary in relation to its social responsibilities. Also it was intended to verify, in the case studied, the commitment of the Judiciary with the required values in the Constitution, as a political agent and administrative acts controller. For this purpose, it was used the bibliographic and documentary research. From the perspective of the phenomenon ofneoconstitutionalism, judicial decisions were confronted with the historical significance of the good and it was verified a glaring incongruity between the constitutional legal system and the role of the judiciary in the State of Paraná. It was concluded that the Judiciary was legitimized to determine the act of falling of the good and that this cultural good of extreme historical importance to society of Ponta Grossa was destroyed with the consent of the State.

Keywords: Cultural heritage. Protection. Judiciary.

\section{Introdução}

O Direito contemporâneo é caracterizado pela passagem da Constituição para o centro do sistema jurídico. O chamado Estado 
Constitucional de Direito, consagrado no século XX, firmou o entendimento de que as normas são válidas não apenas pela legalidade da sua forma de produção, mas também pela congruência de seu conteúdo com as normas e os valores constitucionais. O Direito começa, então, a ser visto como um campo de luta e assume um papel de transformação da realidade da sociedade.

O Judiciário sempre foi um poder coadjuvante, por ser considerado neutro politicamente. Apesar da visibilidade que ganhou por seu empenho em resguardar valores desde o advento do novo Direito constitucional, o Judiciário vem enfrentando o dilema de adaptar sua estrutura organizacional, seus critérios de interpretação e suas jurisprudências às situações inéditas nas relações sociais, fruto do desenvolvimento urbano-industrial, que fez surgir uma sociedade condenada por profundas contradições econômicas, exigindo cada vez mais tutelas diferenciadas para novos direitos sociais e a proteção de interesses difusos e coletivos (FARIA, 2008).

Essas situações inéditas têm colocado o Judiciário diante da necessidade de rever suas funções básicas. Nos tempos atuais, o Judiciário se viu obrigado a dar respostas a demandas para as quais não possui experiência teórica nem jurisprudência firmada, pois já não é suficiente decidir conflitos mediante a simples aplicação de normas abstratas gerais e unívocas a casos concretos

O presente texto discute a possibilidade de o Poder Judiciário, no Brasil atual, declarar um bem como patrimônio cultural, reavaliando o princípio da separação dos poderes e a função do Judiciário frente às suas responsabilidades sociais após a Constituição de 1988. O Judiciário deixa de atuar como mero aplicador mecânico de normas préestabelecidas e passa a assumir, comoadvento do neoconstitucionalismo, a responsabilidade pela efetivação dos direitos sociais e culturais, como o direito à preservação do meio ambiente cultural.

Entre os bens incomensuráveis e heterogêneos do patrimônio cultural, foi escolhido aquele representado pelas edificações, em especial a Cervejaria Adriática, de Ponta Grossa, no estado do Paraná. 
A legislação brasileira, em matéria de meio ambiente cultural, estabeleceu diversos instrumentos de proteção, dentre eles, o tombamento. Trata-se de um ato administrativo declaratório e discricionário. Declaratório na medida em que um bem é cultural não por ser tombado, mas em razão de suas qualidades intrínsecas. Discricionário desde que não haja risco atual que ameace o bem. Embora haja obrigação, o Poder Público pode escolher o momento de tombar, utilizando-se de sua discricionariedade quanto à oportunidade da prática do ato, mas não quanto ao seu exercício.

Se a Administração Pública se omite da prática de um ato e age contrariamente ao interesse público, questiona-se se é possível ao Judiciário exercer o controle desse ato.

A demolição da Cervejaria Adriática foi objeto de ação judicial, julgada improcedente, sob a justificativa de que o Poder Judiciário não é ente legítimo, num Estado Social Democrático de Direito, para reconhecer um bem como cultural - atribuição cabível apenas ao Executivo.

Entendeu o juiz de primeiro grau e o Tribunal de Justiça de Paraná que não cabia ao Judiciário valorar a conveniência da preservação do patrimônio histórico.

Sob o prisma do fenômeno do neoconstitucionalismo, confrontouse a decisão do Judiciário com a importância histórica do bem em questão, bem como a aplicabilidade dos conceitos jurídicos indeterminados, em especial, "excepcional valor" e "feição notável", a fim de, ao final, avaliar se o Poder Judiciário atuou de modo coerente ao ordenamento políticojurídico brasileiro.

\section{As transformações do Judiciário em face de suas responsabilidades sociais}

O objetivo deste tópico, em linhas gerais, é analisar a forma de atuação do Poder Judiciário no Estado contemporâneo, para que, ao 
final, seja possível avaliar se houve congruência entre a decisão do caso concreto em análise com as funções do Judiciário atribuídas pela Constituição Federal de 1988.

A tecnologia, sobretudo nos últimos cinquenta anos, aumentou consideravelmente o nível de complexidade da vida humana. A sociedade tecnológica não aumentou apenas as possibilidades de ação, mas também foi capaz de criar novas formas de ações, como se vê na bioética. O Direito deixa de se preocupar apenas com o passado, para ocupar-se basicamente do futuro, numa tentativa de prevê-lo. É nesse sentido que se deve entender o Estado do Bem-Estar Social (FERRAZ JÚNIOR, 1994).

São as principais características do Estado-providência em relação ao Direito: (a) a predominância do Poder Executivo, que passa inclusive a ingerir na produção do Direito; (b) as sucessivas explosões legiferantes que acarretam a sobrejuridificação da realidade social, o que põe termo à coerência e à unidade do sistema jurídico; o excesso de normas acaba por tornar impossível a aplicação do princípio da subsunção; (c) o Estado passa a ser responsável pelo bem-estar dos cidadãos; os direitos sociais recebem a proteção constitucional e a justiça distributiva se torna base do sistema normativo; o Estado se compromete a proteger juridicamente a liberdade positiva; e (d) a mudança de paradigma da sociedade - do indivíduo para o coletivo - gera a proliferação dos direitos (SANTOS; MARQUES; PEDROSO, 1996).

Essa nova visão de Estado reviu alguns postulados básicos do Estado de Direito, principalmente no que diz respeito à separação entre Estado e sociedade. O Estado Liberal, que se preocupava somente com a liberdade do indivíduo - chamada liberdade negativa - passa a ter o problema da liberdade positiva, que se estende à esfera de participação do cidadão. Dessa forma, o Executivo e o Legislativo vêem suas funções ampliadas, pois agora devem realizar a igualdade material, e não mais garanti-la apenas formalmente (FERRAZ JÚNIOR, 1994).

Passa-se a exigir uma postura ativa do Estado, no sentido de realização/promoção de direitos, nomeados sociais, o que altera a 
função do Poder Judiciário. A ele, não basta julgar o que é certo ou errado; é preciso verificar se o exercício discricionário do poder de legislar e administrar conduz à concretização dos resultados objetivados na Constituição.

Uma das grandes discussões travadas é se o Poder Judiciário tem legitimidade constitucional para determinar um agir político do Estado. A Constituição é um remédio contra a maioria e é o elo que une a política e o Direito. A nova forma de Estado do segundo pósguerra - o Constitucional Social de Direito - fundamenta-se em dois elementos: a democracia e os direitos fundamentais. A existência do Estado Democrático de Direito legitima o agir da Justiça no sentido de exigir da Administração a realização de políticas públicas ordenadas pela Constituição, que nada mais é do que o instrumento que deu forma a esse tipo de Estado (STRECK, 2009).

A questão que se coloca é o problema da legitimidade democrática da função judicial. A maior parte dos países do mundo reserva uma parcela de poder para que seja desempenhado por agentes selecionados com base mérito e no conhecimento específico, para agir com imparcialidade, a fim de preservá-la de paixões políticas. No entanto, o poder do Judiciário é representativo, deve ser exercido em nome do povo e deve contas à sociedade. A ideia de democracia não se resume ao princípio majoritário, que se move por interesse, mas se inspira em valores. A legitimidade democrática do Judiciário não é necessariamente maior que a do Executivo ou Legislativo, que por vezes é afetada por abuso de poder econômico, manipulação dos meios de comunicação etc. (BARROSO, 2005).

O papel do Judiciário é justamente preservar o processo democrático e promover os valores constitucionais, superando, assim, o déficit de legitimidade dos demais poderes.

Se as leis elaboradas pelos parlamentares refletem o pensamento da maioria, esse pensamento não pode justificar as decisões dos juízes. Não se pode confundir pensamento da maioria com democracia, 
pois esta pressupõe justamente o respeito aos direitos fundamentais, inclusive os pertencentes à minoria.

O desenvolvimento/alargamento da democracia consiste não tanto na substituição da democracia representativa pela direta, mas na passagem da democracia na esfera política (na qual o indivíduo é considerado cidadão) para a democracia da esfera social (na qual o indivíduo é considerado na multiplicidade de seus status, ou seja, como pai, filho, cônjuge, trabalhador, profissional, administrador, consumidor etc.). Esse desenvolvimento da democracia não pode ser entendido como um novo tipo de democracia, mas como ocupação de novos espaços (BOBBIO, 1986).

O discurso sobre o significado de democracia não pode ser concluído se não atentar para o fato de que, além de forma de governo, também é entendida como o regime caracterizado pelos fins ou valores em direção aos quais determinado grupo político tende e opera. 0 princípio desses fins ou valores adotados em um regime democrático é a igualdade - não a igualdade jurídica, introduzida pelas constituições liberais, mas a social e econômica (ao menos em parte). Dessa maneira, tem-se a chamada "democracia substancial" (BOBBIO, 1986).

Assim, com o advento do Estado Social e da sociedade tecnológica, e para realizar os valores democráticos, exige-se do Judiciário a sua desneutralização, liberando-se o juiz do estrito princípio da legalidade e da responsabilidade exclusivamente retrospectiva, obrigando-o a uma responsabilidade prospectiva, preocupada com a realização das finalidades políticas que a Constituição prescreve, tanto quanto o Executivo e o Legislativo (FERRAZ JÚNIOR, 1994).

Esse fenômeno é conhecido como neoconstitucionalismo. É uma tentativa de efetivar os chamados direito de segunda e terceira dimensão, em razão da inexistência de um sistema de garantia eficaz.

Diante disso, é preciso aprofundar teoricamente esse fenômeno para avaliar como é possível ao Judiciário efetivar os direitos culturais, objeto do caso estudado neste artigo. A ideia de constitucionalização do 
Direito está associada à expansão do conteúdo material e axiológico da Constituição ${ }^{1}$ por todo o sistema, passando a condicionar a validade e o sentido das normas infraconstitucionais. Não é apenas um sistema em si, mas um modo de interpretar todos os ramos do Direito, consagrando os valores inseridos na Constituição (BARROSO, 2005).

O fenômeno da constitucionalização repercute na atuação dos três poderes. No Legislativo, limita a sua discricionariedade na elaboração das leis e impõe-lhe deveres de atuação para a realização de direitos e programas postos na Constituição. No Executivo, além de também limitar a sua discricionariedade e impor deveres de atuação, ainda fornece fundamento de validade para a prática de atos de aplicação direta e imediata da Constituição, independentemente da interferência do Legislativo. Quanto ao Judiciário, serve como parâmetro para o controle de constitucionalidade e condiciona a interpretação de todas as normas do sistema (BARROSO, 2005).

Nos últimos anos, o Poder Judiciário teve uma vertiginosa ascensão institucional, deixando de ser um departamento essencialmente técnico para desempenhar um papel político. Independentemente de sua função ter natureza política, seus métodos de atuação e fundamentação são jurídicos (BARROSO, 2005).

Aseparação dos poderes, segundo Bonavides (1993), é técnica em declínio, visto que se assenta em razões de formalismo e na proteção de direitos individuais, conforme o teor clássico advindo do liberalismo. Ela foi indiscutivelmente perigosa quando caiu na contradição e na antítese de determinar o enfraquecimento do Estado, segundo a lógica liberaldemocrata. À medida que o constitucionalismo passou a se preocupar com o seu conteúdo, para deixar de ser forma e se converter em

Cumpre ressaltar que este artigo não ignora o fato de que a Constituição não é somente uma "carta de boas intenções", e sim uma mistura heterogênea de interesses de classes econômicas, cumulada com paternalismos, reserva de mercado e privilégios. No entanto, tais críticas não serão analisadas neste trabalho. 
substância, abrangendo novas áreas da realidade social, esse princípio passou a ter interesse secundário, por ter deixado de corresponder ao sentido atual de organização democrática.

O princípio da separação dos poderes foi necessário em outros tempos, em razão dos fatos históricos já descritos para assegurar a liberdade do homem. Atualmente, é um princípio relativizado, em virtude das contradições e incompatibilidades que encontra perante o aumento das responsabilidades sociais do Estado e da posição em que deve se colocar para proteger não só os direitos à liberdade, mas todos os previstos na Constituição.

Isso se deve pela atuação criativa que exerce o intérprete, pela atribuição de sentido aos conceitos jurídicos indeterminados e pela realização de escolhas entre as soluções possíveis, mas também em razão de suas decisões afetarem o equilíbrio entre os poderes, em função do controle que exercem sobre eles.

O Direito contemporâneo é caracterizado pela passagem da Constituição para o centro do sistema jurídico, no qual deve ter uma supremacia material, axiológica. Deve ela transformar-se num filtro para todo direito infraconstitucional. Esse fenômeno, conhecido como constitucionalização do Direito, é uma mudança de paradigma que deu novo sentido e alcance a ramos tradicionais do Direito, como o Direito Administrativo, a ser aprofundado no terceiro tópico.

Os marcos teóricos do novo Direito Constitucional são: a) o reconhecimento da força normativa à Constituição; b) a expansão da jurisdição constitucional; e c) o desenvolvimento de uma nova dogmática de interpretação constitucional (BARROSO, 2005).

O primeiro sobreveio à $2^{\mathrm{a}}$ Guerra Mundial e teve início na Alemanha e na Itália. Vale dizer que às normas constitucionais foi atribuído o status de norma jurídica, e não mais de um documento essencialmente político, de aplicação discricionária. Passaram a ser normas dotadas de imperatividade, como todas as normas jurídicas, e protegidas por 
mecanismos próprios de coação. Esse debate só chegou ao Brasil na década de 1990, visto que o país padecia de patologias ligadas ao autoritarismo (BARROSO, 2005).

O segundo, baseado no modelo americano da supremacia da Constituição, positivou os direitos fundamentais, sujeitando sua proteção ao Judiciário, visto que antes de 1945 vigorava em grande parte da Europa um modelo de supremacia do Poder Legislativo, com a soberania do Parlamento na Inglaterra e com a concepção francesa da lei como expressão da vontade geral. Após essa mudança de paradigma, a adoção de modelos de controle de constitucionalidade e a criação de tribunais constitucionais irradiaram-se pelo mundo.

Por fim, o terceiro decorre naturalmente do primeiro. No entanto, em razão das especificidades das normas constitucionais, a doutrina e a jurisprudência desenvolveram um elenco próprio de princípios aplicáveis à hermenêutica constitucional, tais como: o da supremacia da Constituição, o da presunção de constitucionalidade das normas e atos do Poder Público, o da interpretação segundo a Constituição, o da unidade, o da razoabilidade e o da efetividade (BARROSO, 2005).

Os tribunais tiveram que assumir uma parcela da responsabilidade política do Estado. A questão da independência dos tribunais e a sua neutralização política entraram em crise. Com a constitucionalização dos direitos sociais, o verdadeiro critério de avaliação do desempenho judicial passou a ser os efeitos extrajudiciais da atuação dos tribunais, na medida em que esse desempenho deixou de ser exclusivamente retrospectivo para ter uma dimensão prospectiva (SANTOS; MARQUES; PEDROSO, 1996).

A desneutralização do Judiciário põe em xeque a imunidade dos juízes ao questionar a sua real independência. $O$ fato de que 0 processo de nomeação dos juízes de tribunais superiores está em estreita dependência da vontade política do Executivo e do Legislativo vem causando insegurança, e o que é pior, gerada pelo próprio Direito, em razão da vinculação do juiz à lei (SANTOS; MARQUES; PEDROSO, 
1996). Verifica-se uma dependência em relação aos outros dois poderes: depende da vontade deles para ingressar nos tribunais superiores ${ }^{2}$.

Não obstante essa conquista histórica, o Estado Social transformou-se num abismo entre teoria e prática, pois não conseguiu garantir todos os direitos prescritos pelos pactos internacionais e por muitas Constituições. Nos países periféricos, pode-se afirmar que nunca conseguiu.

O problema que enfrenta o Estado Social não é filosófico, mas jurídico, e, num sentido mais amplo, político. Não se trata de saber quais são os direitos do homem, qual a sua natureza e o seu fundamento, e sim qual é o modo mais efetivo de garanti-los para impedir que sejam continuamente violados.

\section{A natureza jurídica do tombamento}

Após entender a mudança de paradigma pela qual passou o Direito a partir da segunda metade do século XX, alterando a interpretação do princípio da separação dos poderes e modificando a forma de atuação dos juízes, é preciso, para compreender as decisões que concluíram que não cabia ao Poder Judiciário decidir sobre a oportunidade e a conveniência da preservação do bem cultural e verificar se essas decisões são coerentes com a atual postura que se está exigindo desse Poder, analisar a natureza jurídica do instituto do tombamento após a Constituição Federal de 1988.

A proteção dos direitos sociais, sob a ótica do constitucionalismo do Estado Democrático de Direito, não se dá mais pelo viés da proteção contra os excessos do Estado, mas trata-se de exigir dele uma atuação positiva no sentido de proteger os direitos sociais.

Da materialidade do texto constitucional, representada pelos valores substantivos que fazem parte do núcleo político da Constituição

\footnotetext{
2 Quando se fala em desneutralização política do Judiciário, não se deve confundir a politização com a política exercida pelo Legislativo e pelo Executivo.
} 
- os direitos sociais e fundamentais -, é possível afirmar que o Estado Democrático de Direito consagra o princípio da democracia econômica, social e cultural (STRECK, 2009).

O Estado Social introduz plenamente os direitos culturais no texto constitucional, e para torná-los efetivos, prevê múltiplas incumbências para o Poder Público. Tem-se agora uma Constituição cultural, como conjunto de princípios e regras com relativa autonomia em matéria de direitos culturais. E mais, fala-se em um Estado de cultura (MIRANDA, 2009).

Considerar um Estado cultural $^{3}$ é importante, já que impõe às normas ordinárias uma maior coerência com a Constituição, garantindo à sociedade o poder de exigir do Estado e do Direito a proteção do meio ambiente cultural.

Com relação à natureza jurídica do tombamento, a doutrina discute se ele é ato discricionário ou vinculado. Di Pietro (2004) e outros administrativistas clássicos consideram o tombamento um ato discricionário, por não ser o bem cultural o único a ser protegido pelo Poder Público que deverá levar em consideração critérios de oportunidade e conveniência em caso de conflito de valores. Diante do caso concreto, se não houver nenhum óbice, evidentemente deverse-á proceder ao tombamento, por isso, a recusa sempre deverá ser motivada, sob pena de abuso de poder.

Segue o mesmo sentido Silva (2003, p. 123), quando diz que "o ato do tombamento, embora discricionário quanto à oportunidade ou à conveniência, é vinculado quanto ao motivo e ao fim". Já Souza Filho (2006, p. 88) adota posição diversa, a qual parece ser a mais adequada:

Se o bem integrante do patrimônio cultural, assim definido pela norma constitucional, está em perigo, com risco de destruição, por exemplo, é dever do Poder Público interferir

Convém alertar para alguns riscos da fórmula "Estado de cultura", como o de se colocar a cultura a serviço do Estado ou da ideologia dominante do Estado. 
para protegê-lo. O Poder Público com competência para tombar passa a ter obrigação de fazê-lo imediatamente e, neste caso, deixa de haver discricionariedade. [...] Por outro lado se não há risco atual que ameace o bem, embora haja obrigação e não mera faculdade, o Poder Público pode escolher o momento de tombar, utilizando-se assim de sua discricionariedade quanto à oportunidade da prática do ato, mas não quanto ao seu exercício.

A problemática apresentada pelo autor reside na avaliação do risco, por ser este um conceito indeterminado. Apresentadas as provas, caberá à autoridade competente a verificação no caso concreto. Isso torna incerta a defesa do bem cultural, uma vez que a subjetividade pode privilegiar o jogo de interesses.

O início do processo de tombamento é o único ato de discricionariedade possível. Depois de iniciado, todos os outros atos são vinculados, exceto duas normas extravagantes: a Lei $n^{\circ}$ 6.292/75, que prevê a homologação do tombamento pelo Ministro da Cultura, e o Decreto-Lei $n^{\circ} 3.866 / 41$, que estabelece a possibilidade de destombamento pelo Presidente da República. No caso de cancelamento, o chefe do Executivo não está vinculado ao parecer técnico do Conselho. Entende-se que essas normativas não foram recepcionadas pela Constituição Federal de 1988, por serem frutos de um regime ditatorial, representando uma decisão política, e não técnica.

Outro aspecto controvertido diz respeito à consideração do tombamento como ato declaratório ou constitutivo. Podem ser encontradas na doutrina três posições a esse respeito. Para alguns, o tombamento é considerado ato declaratório; para outros, seus efeitos são constitutivos; e para uma terceira linha, possui tanto efeitos declaratórios quanto constitutivos.

$\mathrm{Na}$ primeira corrente, encontram-se autores como Meirelles e Mazzilli. Meirelles (1992, p. 485) define tombamento como "a declaração pelo Poder Público do valor histórico, artístico, paisagístico, turístico, cultural ou científico de coisas ou locais que, por essa razão, devam ser 
preservados de acordo com a inscrição em livro próprio". Mazzilli (2006, p. 204) é categórico ao afirmar que

[...] otombamento é forma especial de proteção administrativa a bem de valor cultural, e tem caráter declaratório, ou seja, o atributo do valor cultural deve preceder o tombamento. É porque o bem tem valor cultural que deve ser tombado; o valor cultural não decorre do tombamento, e sim o inverso é que deve ocorrer.

Diverge desse posicionamento Silva (1981), pois assevera que o tombamento modifica a posição jurídica do bem, transformando-o em bem de interesse público.

Para Pires (1994, p. 280), “o status jurídico especial do bem não decorre diretamente da lei, pois o ato administrativo é que concretiza a abstração, individuando o regime jurídico prescrito, constituindo situação inédita para o bem, alterando os direitos a ele imanentes". Nessa linha seguem também Castro, Gasparini, Mello, Cretella Júnior e Medauar.

Posição intermediária ocupa Souza Filho (2006). Para o autor, o tombamento é ato declaratório, e isso fica bem claro ao se acompanhar a evolução histórica. No entanto, em alguns casos, o tombamento é ato declaratório que reconhece o valor cultural de determinado bem, mas os seus efeitos em relação ao proprietário e a terceiros são constitutivos.

Em 1937, a Lei de Tombamento estabelecia que integravam o patrimônio histórico e artístico brasileiro somente os bens tombados. Dessa forma, o tombamento era ato constitutivo, haja vista que a inscrição do bem em um dos livros do tombo o revestia de uma proteção que até então não Ihe era garantida. Essa situação foi modificada com a promulgação da Constituição Federal de 1988, que alterou a nomenclatura do patrimônio histórico e artístico para patrimônio cultural, ampliando a sua proteção ao não exigir o tombamento para que um bem seja reconhecido como integrante do patrimônio cultural, a exemplo dos monumentos nacionais e bens arqueológicos. Quanto a esses bens tombados ope legis, o tombamento é totalmente ato declaratório. Entretanto, em relação aos demais bens, o ato de tombar é declaratório, 
mas seus efeitos são constitutivos. Essa evolução jurídica se reflete no sistema de proteção, permitindo tanto a ação popular quanto a ação civil pública para bens reconhecidamente culturais, mas que não foram tombados (SOUZA FILHO, 2006).

A jurisprudência não é pacífica nesse tema, mas grande parte tende para a possibilidade de o Judiciário declarar o valor histórico e cultural de um bem .

Após compreender como o tema "patrimônio cultural", em especial o tombamento, está inserido no sistema jurídico ambiental brasileiro, faz-se necessário o aprofundamento da análise desse instituto sob o prisma do Direito Administrativo após a Constituição Federal de 1988, principalmente no tocante aos aspectos de discricionariedade restritiva do tombamento e no campo de atuação do Judiciário nessa matéria. Ao final, um caso específico dará concretude a esta obra. Por meio dele, será possível entender se a mudança de paradigma pelo qual passou o Judiciário está sendo vivenciada na prática ou ainda persistem resquícios do pensamento jurídico tradicional.

\section{0 controle judicial dos atos administrativos discricionários}

A submissão dos atos e contratos da Administração Pública ao controle jurisdicional é uma decorrência do Estado de Direito. Vale ressaltar que Estado de Direito não é apenas a submissão do Estado à lei, porque se assim o fosse, qualquer Estado seria válido, mesmo aquele que cometesse as maiores atrocidades, como os Estados totalitaristas. São também características do Estado Democrático de Direito a separação dos poderes - mitigada, como já visto -, o respeito aos direitos fundamentais e o controle jurisdicional.

A possibilidade de controle judicial dos atos administrativos discricionários, como é o tombamento, regra geral, é reflexo da

Ver Al - 6574165300/TJSP; Apelação Cível 1997.001063-0/TJSC; DGJ 43725927.2008.8.09.0011/ TJGO. 
relativização do princípio da separação dos poderes. $O$ controle jurisdicional é a garantia de um Estado de Direito e, no Brasil, sofreu forte influência da Constituição americana, do judicial review. Nossa Constituição prevê várias formas de controle do Judiciário, uma vez que o acesso ao Judiciário foi ampliado, conforme prescreve o art. $5^{\circ}, \mathrm{XXXV}$, da Constituição Federal, segundo o qual qualquer lesão ou ameaça de lesão poderá ser submetida à apreciação do Poder Judiciário. Garantias foram ratificadas pela Constituição Federal e tiveram seu conteúdo ampliado, como a ação popular e a ação civil pública.

O controle judicial dos atos discricionários é possível para razoável parte da doutrina e da jurisprudência. Como já referido, a discricionariedade, tema de diferentes posicionamentos, é muito restrita na área ambiental.

Grandes administrativistas brasileiros, como Meirelles, Di Pietro, Figueiredo e Gasparini, afirmam que é possível o controle jurisdicional do ato discricionário, desde que não invadam o mérito desse ato. Esse é o posicionamento de boa parte da jurisprudência, em especial do STJ e STF5.

Dentre os juristas que perfilham posicionamento mais moderno, no sentido de admitir um controle maior do Judiciário em relação aos atos administrativos discricionários, encontra-se Krell (2004, p. 53-54):

Não há mais dúvidas, no Brasil, de que todo e qualquer ato administrativo, inclusive $o$ ato discricionário e também aquele decorrente da valoração administrativa dos conceitos indeterminados de prognose, é suscetível de um controle jurisdicional mínimo, baseado nos princípios constitucionais e nos princípios gerais de Direito. $\mathrm{Na}$ atual fase 'pós-positivista', que foi instaurada com a ampla positivação dos princípios gerais de Direitos nos novos textos constitucionais, os atos administrativos discricionários não devem ser controlados somente por sua legalidade,

5 Ver STJ, RMS 20.271/GO; STJ, MS 13742, DF 2008/0177332-3; STJ RMS 20.745/RS. 
mas por sua juridicidade. Essa 'principialização' do Direito brasileiro (proibição da arbitrariedade, razoabilidade, proporcionalidade, igualdade, proteção da confiança legítima, etc.) aumentou a margem da vinculação dos atos discricionários.

O Judiciário pode apreciar aspectos de legalidade e legitimidade, como anteriormente mencionado, e analisar se o Poder Público não ultrapassou os limites da discricionariedade, como a teoria do desvio do poder e a teoria dos motivos determinantes ou princípio da realidade, como quer Moreira Neto (2002). Essa teoria afirma que os motivos alegados pela Administração só serão válidos se forem verdadeiros. Outros limitadores são os conceitos legais indeterminados (DI PIETRO, 2004).

Os denominados conceitos jurídicos indeterminados, também chamados de cláusulas gerais, como é o caso das expressões "excepcional valor" e "feição notável", constantes na definição de patrimônio cultural, são considerados uma técnica legislativa que ganhou espaço com o fenômeno do neoconstitucionalismo e se utiliza de expressões de textura aberta que fornecem um início de significado a ser completado pelo intérprete, levando-se em consideração as circunstâncias do caso concreto (BARROSO, 2009).

O recurso a essa forma de enunciação de normas não é privilégio do Direito Constitucional, mas está disseminado em todos os ramos do Direito. Espécie do gênero "cláusulas gerais" são expressões de sentido maleável, destinadas a lidar com situações nas quais o legislador não pôde ou não quis especificar de forma detalhada, deixando a critério do intérprete a sua melhor adequação ao caso (BARROSO, 2009).

Não se pode confundir o poder de valoração dos conceitos jurídicos indeterminados com o poder discricionário. Ambos os institutos são frutos da impossibilidade do Direito de prever todas as hipóteses de condutas a serem seguidas. Atribuir sentido a um conceito jurídico determinado requer técnica baseada em regras de experiência, precedentes ou elementos externos ao Direito. Já a utilização do poder 
discricionário compreende a formulação de juízos de oportunidade e conveniência, deixando a norma uma liberdade de escolha ao intérprete. Recordando a estrutura da norma jurídica que contém a previsão de um fato e a atribuição a ele de consequências jurídicas, pode-se dizer que, enquanto os conceitos jurídicos indeterminados integram a descrição do fato, os juízos discricionários possibilitam ao intérprete a escolha das consequências jurídicas (BARROSO, 2009).

O controle jurisdicional, por óbvio, há de ser realizado à luz dos princípios, em especial, firmados pelo artigo 37 da Constituição. Para Grau, é devida, além de possível, a revisão dos motivos (oportunidade) e do objeto (conveniência) do ato administrativo pelo Poder Judiciário. O pleno conhecimento dos fatos para os juízes é indispensável, a fim de que ele possa distinguir o que é legalidade e o que é mérito. O Ministro, em uma de suas decisões, ratifica a possibilidade do controle do mérito dos atos administrativos.

Como a atividade da Administração é infralegal administrar é aplicar a lei de ofício, dizia Seabra Fagundes -, a autoridade administrativa está vinculada pelo dever de motivar os seus atos. Assim, a análise e ponderação da motivação do ato administrativo informam o controle, pelo Poder Judiciário, da sua correção.

O Poder Judiciário verifica, então, se o ato é correto. Não, note-se bem - e desejo deixar isso bem vincado -, qual o ato correto.

$\mathrm{E}$ isso porque, repito-o, sempre, em cada caso, na interpretação, sobretudo de textos normativos que veiculem "conceitos indeterminados" (vale dizer, noções), inexiste uma interpretação verdadeira [única correta]; a única interpretação correta - que haveria, então, de ser exata - é objetivamente incognoscível (é, in concreto, incognoscível). Ademais, é óbvio, o Poder Judiciário não pode substituir-se à Administração, enquanto personificada no Poder Executivo. Logo, o Poder Judiciário verifica se o ato é correto; apenas isso.

Nesse sentido, o Poder Judiciário vai à análise do mérito do ato administrativo, inclusive fazendo atuar as pautas 
da proporcionalidade e da razoabilidade, que não são princípios, mas sim critérios de aplicação do direito, ponderados no momento das normas de decisão. (STF, RMS 24699, 2009).

A jurisprudência brasileira, em alguns casos, tem admitido a tese do controle jurisdicional do mérito do ato administrativo, segundo interpretação constitucional ${ }^{6}$. Nos países em que há tribunais administrativos, como na França e na Itália, a questão do controle de mérito pode ser mais facilmente superada.

Para Moreira Neto (2002), o Judiciário não possui diretamente a tutela da legitimidade, uma vez que esta cabe ao povo e aos seus representantes eleitos, mas a possui indiretamente, a partir da "definição positivada de legitimidade" contida na norma, seja implícita ou explicitamente, utilizando-se dos instrumentos da realidade e da razoabilidade.

Logo, não há como fugir da conclusão de que o controle jurisdicional dos atos administrativos se estende também aos motivos, tanto o legal quanto o de fato, a fim de que o Judiciário não seja relegado a mero endossante da autoridade administrativa.

\section{O caso da demolição da Cervejaria Adriática em Ponta Grossa, Paraná}

Após discorrer no primeiro tópico sobre a forma de atuação do Judiciário e o que se exige dele hodiernamente, e compreender, no segundo tópico, os reflexos dessa atuação em temas específicos, como o patrimônio cultural, analisar-se-á como essas questões teóricas têm ocorrido na prática. Para tanto, optou-se pelo estudo de um caso, ocorrido em Ponta Grossa, estado do Paraná, que talvez somente após sua conclusão tenha tido maior repercussão.

6 Ver STJ, Resp 493.811/SP; TRF-1, Apelação Cível 1541/AM 2003.32.00.001541-2. 
Em 2 de outubro de 1996, o Ministério Público do Paraná (MP) distribuiu na Comarca de Ponta Grossa uma "ação cautelar inominada para proteção de patrimônio histórico" em face da Companhia Sulina de Bebidas Antárctica (Autos $n^{\circ} 760 / 1996,2^{a}$ Vara Cível), por ter tomado conhecimento de que o imóvel, sede da empresa, considerado pelo MP patrimônio histórico da cidade, vinha sendo demolido.

Até o final do século XIX, a cidade de Ponta Grossa era caracterizada como um típico vilarejo da época do império. A população era composta por fazendeiros, negros libertos e escravos, e pequenos comerciantes que atendiam às demandas das fazendas da região. Tal cenário somente se modificou com a construção da Estrada de Ferro do Paraná e a Estrada de Ferro São Paulo-Rio Grande, em 1893 e 1896, respectivamente (CHAVES, 2006).

A partir desses acontecimentos, a população e a cidade cresceram vertiginosamente, e o comércio e a indústria se tornaram a base da economia da cidade, tornando-se referência no sul do Brasil ao longo da metade do século XX. Ponta Grossa, nessa época, desenvolveu uma considerável estrutura industrial. Simbolicamente, a Cervejaria Adriática, fundada em 1893, configurou-se como marco inicial desse processo (CHAVES, 2006).

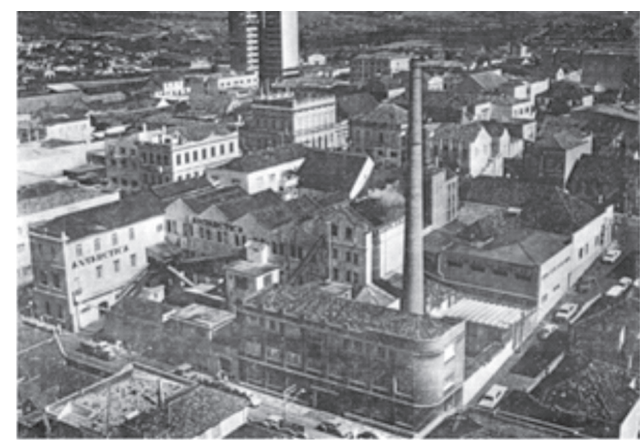

Figura 1 - Cervejaria Adriática 1

Fonte: Casa da Memória

O imóvel da Cervejaria Adriática era considerado um dos últimos remanescentes da arquitetura tradicional do início do século $X X$, 
representando um marco histórico da industrialização da cidade de Ponta Grossa.

A ação visava à abstenção, pelo proprietário do imóvel, de qualquer ato ou obra de demolição. Ressalta-se que o objetivo da ação cautelar, de natureza preparatória, é apenas fazer cessar o perigo de dano até que o mérito ao final da ação principal seja julgado. Ou seja, a pretensão era apenas cessar a demolição até que o Judiciário, na ação principal, reconhecesse e declarasse o valor cultural do bem agredido, para então protegê-lo. Para isso, arguiu o Ministério Público, como fumus boni juris, requisito da ação cautelar, que será estudado adiante, que um bem não necessitava ser tombado para ser considerado patrimônio cultural, e em razão dessa sua natureza, deveria ser protegido pelo Judiciário, visto que o ato administrativo de tombamento simplesmente declara, dá forma a uma situação fática pré-existente.

Contrariamente a essa posição, contestou o proprietário alegando que o ato de demolição era perfeitamente legal, uma vez que possuía autorização do Poder Público. Afirmou que previamente solicitou parecer da Coordenadoria Estadual do Patrimônio Histórico, conforme exigência da Lei 4.856/927 , a qual não se opôs à demolição do imóvel, conforme trecho a seguir (Informação 013/96): "Analisando a solicitação contida no OF. 06/CPD/SMP informamos que o imóvel em questão não é tombado pelo Estado do Paraná, não havendo por parte desta curadoria nenhum impedimento para demolição do mesmo."

Dessa forma, ratificou o proprietário/contestante que não se negava ao Poder Público o poder de constituir seu patrimônio histórico, desde que o fizesse mediante lei ou ato administrativo, não podendo o Judiciário interferir na discricionariedade do Executivo ou do Legislativo.

\footnotetext{
"Art. 41 - Nenhuma edificação localizada na Zona Central poderá ser demolida ou reformada sem prévio parecer da Coordenação Estadual do Patrimônio Histórico, até que o Poder Executivo promova o levantamento e mapeamento, bem como a regulamentação legal pertinente ao tombamento e preservação das construções de valor artístico, histórico ou cultural nela existentes, submetendo-os à aprovação da Câmara Municipal."
} 
Em um primeiro momento, o juiz de primeiro grau concedeu a liminar e ordenou a suspensão da demolição. Entretanto, logo após a contestação do proprietário, revogou-a. A discussão em relação ao valor cultural do bem em litígio não chegou sequer a ser abordada, visto que o Judiciário (tanto o juiz de primeiro grau quanto o tribunal) decidiu que não cabia a esse Poder valorar a conveniência da preservação do patrimônio cultural, pois o órgão competente não o fez, conforme se observa nos trechos das decisões.

\section{Sentença}

Declarado o tombamento pela autoridade administrativa, cabe ao Poder Judiciário tão-somente assegurar que atendeu o procedimento às disposições legais atinentes à espécie. Inadmissível, por conseguinte, substituição, pelo Judiciário, da autoridade competente para a emissão de juízo de valor sobre os motivos que ensejaram o tombamento.

Em outras palavras, atribui-se exclusivamente à autoridade administrativa a competência para a qualificação dos bens, tratando-se de matéria de mérito administrativo a determinação de seu eventual valor histórico-cultural. $[\ldots]$

Desta forma, a declaração do tombamento do prédio principal, única unidade ainda não demolida de toda a construção, caracterizar-se-ia não como simples limitação de direito, mas como sacrifício de um direito, hipótese de desapropriação ou, quando menos, de tombamento cumulado com indenização, haja vista a perda da destinação econômica do bem, como pretendida pelo contestante.

Admitir-se quaisquer dessas possibilidades de restrição, contudo, constituiria medida de justiça? O pretenso valor histórico e cultural da referida edificação suplantaria, uma vez reconhecido, o direito à fruição da propriedade, constitucionalmente assegurado à contestante?

Consoante já foi afirmado, não compete ao Poder Judiciário valorar a conveniência da preservação do patrimônio 
histórico nacional, impondo ao particular um ônus cuja necessidade de determinação não foi reconhecida pelo órgão para tanto competente.

É atribuição do Judiciário, isto sim, garantir a observância dos preceitos legais, tanto quanto o respeito à legalidade, considerada em seu sentido mais amplo, sejam os atos dos sujeitos ao seu controle oriundos da atividade de particulares ou praticados por agentes da Administração Pública.

O que emerge desses autos, com efeito, é a perfeita legalidade dos atos praticados pela contestante, no exercício de um direito seu, perfeitamente legítimo, bem como a ausência de interesse público - expressa em manifestação oportuna da autoridade administrativa competente - na preservação do referido bem.

\section{Acórdão}

A razão, contudo, está com o prolator desta. Com efeito, embora em cognição sumária, impunha-se o exame da aparência do bom direito. E para fazê-lo tinha o juiz que servir-se da prova existente nos autos e que consistia em documento pelo qual o órgão administrativo encarregado informou, atendendo solicitação feita pela Prefeitura Municipal, não haver impedimento para demolição do prédio, que não era tombado pelo Estado do Paraná, esclarecendo, posteriormente, que embora nada tendo contra a demolição, poderia a preservação ser feita no âmbito regional. Foi em vista dessa informação e do alvará de demolição que desacolheu o pedido, entendendo inexistente o fumus boni juris, vez que a prova produzida desaconselhava deferi-lo, sob pena de impedir o pleno exercício do direito de propriedade, e porque não cabia ao Judiciário valorar a conveniência da preservação do patrimônio histórico nacional.

Apesar de fundamentalmente sintéticas, as decisões apontam três posicionamentos teóricos dos julgadores: 
O tombamento é um ato administrativo de natureza discricionária e constitutiva de competência do Poder Executivo;

O mérito dos atos administrativos discricionários não pode sofrer controle judicial, visto que a valoração da conveniência (decisão política) da preservação é atribuição do Executivo;

A existência de um campo de não interferência do Judiciário na atuação do Executivo, consagrando o princípio da separação dos poderes.

No discorrer dos tópicos deste artigo, puderam ser observadas diversas incongruências em relação ao que foi discutido até o momento. O fenômeno do neoconstitucionalismo, explicitado no primeiro tópico, também alcançou o direito administrativo, principalmente quanto à aplicabilidade dos princípios constitucionais na relação Administração/ administrado, em especial:

1.1) Na redefinição da ideia de supremacia do interesse público sobre o privado;

1.2) Na vinculação do administrador à Constituição, e não apenas à lei ordinária - supera-se a ideia restrita de vinculação positiva do administrador à lei, ou seja, sua atuação estava pautada naquilo que o legislador determinasse ou autorizasse. $O$ administrador deve, independentemente de manifestação do legislador, atuar de acordo com a Constituição;

1.3) $\mathrm{Na}$ possibilidade de controle judicial do mérito do ato administrativo - ao Judiciário é permitido não somente o controle sobre a legalidade do ato (competência, forma e finalidade), mas também quanto ao seu mérito (motivo e objeto), incluindo aqui a conveniência e a oportunidade, em razão da consagração de princípios como moralidade, eficiência e a razoabilidade-proporcionalidade.

Isso se deve, principalmente, pela atuação criativa que pode exercer o intérprete, aqui se leia administrador ou julgador, pela atribuição de sentido aos conceitos jurídicos indeterminados, sempre de acordo com a Constituição. 


\section{Conclusão}

As decisões do caso estudado revelaram uma flagrante incongruência entre o sistema constitucional e a atuação do Judiciário.

O controle judicial do mérito dos atos administrativos é tese amplamente debatida pelos tribunais e preponderantemente aceita no Supremo Tribunal Federal. O Judiciário eximiu-se de suas responsabilidades ao esconder-se implicitamente sob o princípio da separação dos poderes. Esse princípio não deve mais ser interpretado sob a ótica clássica do liberalismo, como garantia aos direitos individuais, mas à luz da Constituição Federal, como um sistema de freios e contrapesos e como forma de fortalecer o Estado, a fim de que os valores estabelecidos na Carta Magna, em especial o interesse público, sejam alcançados.

A defesa judicial dos interesses difusos atribui ao juiz o poder de definir o interesse público no caso em concreto, sendo essa função não mais passiva, limitada apenas ao controle da legalidade, mas ativa, no sentido de assumir a responsabilidade pela avaliação dos fatos e por um resultado justo (KRELL, 2004). Impedir o controle judicial do mérito dos atos administrativos é conceder ampla discricionariedade em matéria de direitos fundamentais indisponíveis, o que pode tornar os atos não discricionários, mas arbitrários.

A sentença faz um juízo de valor equivocado ao entender que em um conflito entre o direito de propriedade e o direito à cultura, prevalece a propriedade. Não competia ao juiz, no momento da integração da norma, substituir as decisões/opções valorativas da Constituição pelas suas. A Constituição, ao recepcionar o instituto do tombamento, entendido como uma limitação ao direito de propriedade, fez uma opção política de priorizar os direitos difusos/coletivos face aos direitos individuais.

O fato de o prédio da Cervejaria ter sido demolido quase na sua totalidade, não impediria que o Judiciário declarasse o seu valor cultural e determinasse ao agente do ato ilegal a reparação do dano. 
A sentença compreendeu erroneamente o instituto do tombamento como um ato constitutivo, quando na verdade é considerado meramente declaratório. Isso significa que o bem cultural assim o é em razão de suas qualidades intrínsecas, e não porque uma autoridade competente emitiu ato administrativo. Logo, se um bem é cultural de per si, nada impede que a autoridade judiciária determine a sua proteção.

A Constituição Federal declarou tombados todos os documentos e sítios ligados aos antigos quilombos. Essa declaração é a afirmação de que é possível não só ao Poder Executivo, mas também ao Legislativo e ao Judiciário, tombar um bem, mesmo que o ato de inscrição no livro do tombo tenha de ser feito por funcionário competente (SOUZA FILHO, 2006).

A atuação do Judiciário do Estado do Paraná permitiu a demolição de um bem que, segundo os dados coletados e analisados, era, e continua sendo, na memória, referência para a população ponta-grossense.

A ação popular e a ação civil pública são instrumentos processuais de proteção ao patrimônio cultural, cuja finalidade é pleitear, perante o Judiciário, a declaração de que o bem em questão tem valor cultural e, portanto, é passível de tombamento.

A produção legislativa da década de 1960, em prol da defesa do meio ambiente, veio a ser consolidada com a Constituição de 1988, que ampliou o conceito de patrimônio cultural brasileiro, incluindo o tombamento como um dos principais instrumentos de proteção, deixando claro, no artigo $216, \S 5^{\circ}$, que, não obstante o Decreto-Lei $n^{\circ}$ 25/37, o patrimônio cultural brasileiro não se resume ao conjunto dos bens tombados (SOUZA FILHO, 2006).

Não obstante os inúmeros avanços consagrados na Constituição Federal de 1988, esse instrumento normativo muitas vezes tem sido ineficaz, como se verificou no caso da Cervejaria Adriática. A positivação de inúmeros direitos foi uma grande conquista e a sua eficácia é o grande desafio. O fenômeno do neoconstitucionalismo é um dos movimentos que nasceu da luta pela efetivação da Constituição. 
Apesar do problema da efetivação e de outros estruturais, derivados em grande parte das inúmeras emendas que tem sofrido, não é possível negar que a Constituição Federal é o grande marco do ordenamento jurídico brasileiro e um forte instrumento de luta para a transformação da realidade social.

\section{Referências}

BARROSO, Luís Roberto. Curso de direito constitucional contemporâneo: os conceitos fundamentais e a construção do novo modelo. São Paulo: Saraiva, 2009.

BARROSO, Luís Roberto. Neoconstitucionalismo e constitucionalização do direito: o triunfo tardio do direito constitucional no Brasil. Jus Navigandi, Teresina, v.9, n.851, 1 nov. 2005. Disponível em: <http://jus2.uol.com.br/doutrina/texto.asp?id=7547>. Acesso em: 20 mar. 2009.

BOBBIO, Norberto. Estado, governo, sociedade: para uma teoria geral da política. Tradução Marco Aurélio Nogueira. 4 ed. São Paulo: Paz e Terra, 1986.

BONAVIDES, Paulo. Do estado liberal ao estado social. Belo Horizonte: Del Rey, 1993.

BRASIL. Supremo Tribunal Federal. Limites de atuação do poder judiciário, RMS 24699, União versus Bernardo Rosenberg, Relator Min. Eros Roberto Grau. Diário de Justiça, Brasília, 24 mar. p. 36. 2006.

CHAVES, Niltonci B. Do centro comércio e indústria ao selo social. Ponta Grossa: UEPG, 2006.

DI PIETRO, Maria Sylvia Zanella. Direito administrativo. 17. ed. atual. São Paulo: Atlas, 2004.

FARIA, José Eduardo. Direitos humanos, direitos sociais e justiça. São Paulo: Malheiros, 2008. 
FERRAZ JÚNIOR, Tércio Sampaio. O judiciário frente à divisão de poderes: um princípio em decadência? Revista USP, São Paulo, n. 21, p. 13-21, 1994.

KRELL, Andréas J. Discricionaridade administrativa e proteção ambiental: o controle dos conceitos jurídicos indeterminados e a competência dos órgãos ambientais. Porto Alegre: Livraria do Advogado, 2004.

MAZZILLI, Hugo Nigro. A defesa dos interesses difusos em juízo. 19 ed. São Paulo: Saraiva, 2006.

MEIRELLES, Hely Lopes. Direito administrativo brasileiro. 17. ed. atual. São Paulo: Malheiros, 1992.

Recebido em: 24/02/14

Aceito em: 17/08/14 